\title{
The imbalance between Tregs, Th17 cells and inflammatory cytokines among renal transplant recipients
}

\author{
Liang Ma ${ }^{1,3+}$, Huimao Zhang ${ }^{1 \dagger}$, Kebang Hu², Guoyue Lv', Yaowen $\mathrm{Fu}^{2}$, Desalegn Admassu Ayana ${ }^{4}$,
} Pingwei Zhao ${ }^{1,5^{*}}$ and Yanfang Jiang ${ }^{1,5^{*}}$

\begin{abstract}
Background: A significant barrier to organ transplantation is the cellular rejection that occurs and mediated by antibodies, $T$ cells, and innate immune cells. This study was aimed to determine the number of $\mathrm{CD} 4^{+} \mathrm{CD} 25^{+} \mathrm{Foxp}^{+}$Treg, CD4 $4^{+}$IFN- $\gamma^{-} \mathrm{IL}-17^{+}$Th17, CD4 ${ }^{+} \mathrm{IFN}-\gamma^{+} \mathrm{IL}-17^{-}$Th1 and CD4 ${ }^{+} \mathrm{IFN}-\gamma^{+} \mathrm{IL}-17^{+}$Th1/17 cells in renal transplant recipients (RTR).

Methods: Renal transplantation was performed for a total of 35 patients with end-stage renal failure. The number of $\mathrm{CD}^{+}{ }^{+} \mathrm{CD} 25^{+}$Foxp3 $^{+}$Treg, CD4 $4^{+} \mathrm{IFN}-\gamma^{-} \mathrm{IL}-17^{+}$Th17, CD4 ${ }^{+} \mathrm{IFN}-\gamma^{+} \mathrm{IL}-17^{-}$Th1 and CD4 ${ }^{+} \mathrm{IFN}-\gamma^{+} \mathrm{IL}-17^{+}$Th1/17 cells, and the serum level of IFN- $\gamma$, TNF- $\alpha$, IL-2, IL-4, IL-6, IL-10, and IL-17 were measured in pre- and post-transplant patients and 10 healthy controls ( $\mathrm{HC}$ ) using flow cytometry and Cytometric Bead Array (CBA). The association between the number of different subsets of $C D 4^{+}$T-cells and clinical parameters were analyzed among the pre- and post-transplant patients, and the healthy controls.
\end{abstract}

Results: The number of CD4 $4^{+} \mathrm{IFN}-\gamma^{-} \mathrm{IL}-17^{+}$Th17, CD4 $4^{+} \mathrm{IFN}-\gamma^{+} \mathrm{IL}-17^{-}$Th1 and CD4 ${ }^{+} \mathrm{IFN}-\gamma^{+} \mathrm{IL}-17^{+}$Th1/17 cells were significantly increased in patients with End-Stage Renal Failure (ESRF) compared to the HC. Stratification analysis indicated that AMR (Acute antibody mediated acute rejection), AR (acute rejection) and $\mathrm{CR}$ (chronic rejection) groups displayed greater number of $\mathrm{CD} 4^{+} \mathrm{IFN}-\gamma^{-} \mathrm{IL}-17^{+} \mathrm{Th} 17, \mathrm{CD} 4^{+} \mathrm{IFN}-\gamma^{+} \mathrm{IL}-17^{-}$Th1 and CD4 ${ }^{+}$IFN- $\gamma^{+} I L-17^{+}$Th1/17 cells as well as high level of serum IL-2, IFN- $\gamma$, TNF-a and IL-17. But, the AMR, AR and CR groups have shown lower level of $\mathrm{CD} 4^{+} \mathrm{CD} 25^{+} \mathrm{Foxp}^{+} \mathrm{T}$ cells and serum IL-10 compared to transplant stable (TS) patients. Moreover, the number of Tregs were negatively correlated with the number of Th17 cells in RTR patients. The number of Tregs and Th17 cells were positively correlated with the eGFR and serum creatinine values, respectively.

Conclusion: The imbalance between different types of $\mathrm{CD}^{+} \mathrm{T}$ cells and dysregulated inflammatory cytokines may contribute towards renal transplantation rejection.

\section{Background}

Renal transplantation is used to improve survival and quality of life for patients with end-stage renal disease. In the past, patients often eventually die from complications $[1,2]$ if toxins cannot be removed from the body by hemodialysis. Although renal transplantation is recognized as the gold strategy for treating renal failure, it has several limitations including donor's immune

\footnotetext{
* Correspondence: zhaopingwei@sohu.com; yanfangjiang@hotmail.com ${ }^{\dagger}$ Equal contributors

${ }^{1}$ Genetic Diagnosis Center, The First Hospital of Jilin University, Changchun 130021, China

Full list of author information is available at the end of the article
}

rejection. In order to identify a means of controlling immune rejection, further illustration on the mechanism of immune rejection in renal transplant recipients (RTR) has great significance.

It is generally accepted that a significant barrier to organ transplantation is the humoral and cellular rejection that can occur and mediated by antibodies, $\mathrm{T}$ cells, and innate immune cells. Cellular immune response play's an equally important role with humoral immune response in allograft rejection [3, 4]. For instance, there is evidence that a disturbed T-cell homeostasis play's a critical role in the development of acute graft rejection episodes. The main $\mathrm{T}$ subsets which are pivotal for this T-cell balance consists of 
T-helper 17 (Th17) cells and regulatory $\mathrm{T}$ (Treg) cells [5-7]. In addition to well characterized Th1 and Th2 lymphocytes, additional subsets called Th17 cells, which selectively produce IL-17, have joined the effector $\mathrm{CD} 4^{+} \mathrm{T}$ cell lineage. Imbalanced Th17 and impaired Treg cells have suggested to be involved in the pathogenesis of allograft rejection, such as heart and lung transplantations [8-11]. Previous studies have suggested that Th17 cells are important for clearance of a variety of pathogens and are associated with numerous autoimmune and inflammatory conditions [12]. In addition, Th17 cells have also been implicated in acute and chronic rejection in animal models of allograft transplant [13-16]. Interestingly, the function of self-reacting effector Th17 cells is controlled by Tregs, yet another subpopulation of $\mathrm{CD}^{+} \mathrm{T}$ lymphocytes which express transcription factor FoxP3 [17]. Tregs are important regulators of immune tolerance and can actively suppress pro-inflammatory $\mathrm{T}$ cell responses $[18,19]$. Quantitative and/or qualitative deficiencies of Tregs have been associated with the development of organ transplantation rejection [20-23]. Previous studies in animal models have shown that a deficiency in Tregs favors kidney transplantation rejection [20,21], though their mechanism in clinical studies remains unclear. Human Tregs are not as well characterized as their murine counterparts; in part this is due to restrictions and limitations of clinical studies. Furthermore, the characterization of Tregs in humans is more complex $[24,25]$. Human Tregs are $\mathrm{CD} 4^{+} \mathrm{CD} 25^{+}$and their development and function depends on the forkhead family transcription factor (Foxp3) expression [26-28]. Recent study has shown that a lower frequency of circulating $\mathrm{CD}^{+}{ }^{+} \mathrm{CD} 25^{+} \mathrm{Foxp}^{+} \mathrm{T}$ cells was detected in RTR patients, and the percentages of $\mathrm{CD} 4^{+} \mathrm{CD} 25^{+} \mathrm{Foxp} 3^{+} \mathrm{T}$ cells were negatively associated with eGFR of RTR [29]. However, little is known about the number of Tregs and Th17 cells, and their association with different types of rejection in RTR patients.

In addition, studies have shown that some inflammatory cytokines, such as Th1-type cytokine (IFN- $\gamma$ ) and Th17-type cytokine (IL-17), are also associated with the development of rejection [30-33]. For instance, IFN- $\gamma$ can mediate separate functions at the same target organ during Graft-versus-host disease (GVHD), and IL-17 can induce the expression of proinflammatory tumor necrosis factor (TNF)- $\alpha$, chemotactic protein (MCP)-1 and macrophage inflammatory protein (MIP)-1 to promote tissue inflammation [30-32]. Furthermore, IL-17 can also promote the differentiation and maturation of dendritic precursor cells, increased cell surface expression of CD80, CD40 and major histocompatibility complex (MHC)-II antigen [33]. However, the role of these inflammatory cytokines in different types of renal transplantation rejection has not been clarified.
In the current study, we characterized the number of circulating $\mathrm{CD} 4^{+} \mathrm{CD} 25^{+}$Foxp $3^{+}$Tregs and Th17 cells, and the concentration of serum inflammatory cytokines in different RTR patients and HCs to determine their potential association with clinical measures in the patients.

\section{Methods \\ Subjects}

A total of 35 patients (20 male and 15 female), 31-48 years of age (median age 38), with an end-stage renal failure (ESRF) waiting for renal transplantation were recruited from the inpatient service of the First Hospital of Jilin University, Changchun, China. Ten gender, ethnicity and age-matched HCs were included in the study. Individual patients with ESRF were diagnosed according to the criteria [34]. Individual patients were treated with conventional immunosuppressors (Cyclosporine, azathioprine or mycophenolate mofetil and/or steroids) twice a day for three days. All patients had compatible HLAgene matches and the number of those patients who had HLA (A, B, DR) mismatches were less than two. Individuals were excluded if she/he had a history of previous renal transplantation or surgical procedure. Written informed consent was obtained from individual participants. The experimental protocol was established according to the guidelines of the 1975 Declaration of Helsinki and approved by the Human Ethics Committee of Jilin University, China.

\section{Study groups}

Transplant patients were divided into four groups according to graft function (based on estimated glomerular filtration rate (eGFR) or serum creatinine level) and posttransplant rejection time (after 12 weeks) as well as the Banff Classification [35]. The four groups included were: (a) Transplant Stable (TS) $(n=13)$ : Recipients with stable graft function under conventional immunosuppressors (Cyclosporine, azathioprine or mycophenolate mofetil and/or steroids) and without clinical and laboratory features suggestive of rejection (serum creatinine level: < 150 umol/L; eGFR: $\geq 50$ ) in 12 weeks; There was no biopsies of these individuals because they have normal and stable graft function; (b) Acute antibody mediated acute rejection (AMR) $(n=8)$ : Recipients under conventional immunosuppressors with clinical symptoms (fever, graft pain, oliguria or anuria) and progressive renal function deterioration (serum creatinine level: $\geq 150 \mathrm{umol} / \mathrm{L}$; eGFR: < 50) during 1 week; The rejection of these individuals was confirmed by biopsy according to Banff criteria; (c) Acute rejection (AR) $(n=7)$ : Recipients under conventional immunosuppressors with clinical symptoms (fever, graft pain, oliguria or anuria) and progressive renal function deterioration (serum creatinine level: $\geq 150 \mathrm{umol} / \mathrm{L}$; eGFR: < 50) during 2 to 12 weeks; The rejection of these individuals was confirmed by biopsy according to Banff 
criteria; (d) Chronic rejection (CR) ( $n=7)$ : Recipients under conventional immunosuppressors with clinical symptoms (fever, graft pain, oliguria or anuria) and progressive renal function deterioration (serum creatinine level: $\geq 150 \mathrm{umol} /$ L; eGFR: < 50) after 12 weeks; The rejection of these individuals was confirmed by biopsy according to Banff criteria. These group of patients who received kidney transplant had no post-transplant malignancy and infective complications. In case of rejection response, patients withdrew from the follow-up and receive additional anti-rejection treatment, such as methyl prednisolone, anti-thymocyte globulin or anti-CD3 monoclonal antibody as well as plasma exchange.

\section{Clinical measurement}

Peripheral venous blood samples were obtained from individual participants for laboratory test before and after transplant, when rejection-related clinical symptoms appeared. The routine laboratory investigations include complete blood count, serum creatinine, BUN and glomerular filtration rate (eGFR). The laboratory investigations were conducted by scattered turbidimetry using Siemens special protein analyzer (Siemens Healthcare Diagnostics Products, GmbH, Germany).

\section{Isolation and stimulation of PBMCs}

Peripheral venous blood samples were collected after overnight fasting. Peripheral blood mononuclear cells (PBMCs) were isolated by density-gradient centrifugation using Ficoll-Paque Plus (Amersham Biosciences, Little Chalfont, UK). PBMCs $\left(10^{6} / \mathrm{mL}\right)$ were stimulated in duplicate with $50 \mathrm{ng} / \mathrm{mL}$ of phorbol myristate acetate (PMA) and $1.0 \mathrm{mg} /$ $\mathrm{mL}$ of ionomycin (Sigma, St. Louis, MO, USA) in $10 \%$ human $A B$ type sera in RPMI 1640 medium at room temperature in a humidified incubator with $95 \%$ air and $5 \%$ carbon dioxide for $2 \mathrm{~h}$ and then cultured for another $4 \mathrm{~h}$ in the presence of $0.5 \mathrm{mg} / \mathrm{mL}$ of brefeldin A (BFA, Sigma). The control PBMCs were cultured in medium alone.

\section{Flow cytometry analysis}

The frequency of CD4 ${ }^{+} \mathrm{IFN}-\gamma^{+} \mathrm{IL}-17^{-}$Th1, CD4 ${ }^{+} \mathrm{IFN}-\gamma^{-} \mathrm{IL}-$ $17^{+}$Th17, CD4 ${ }^{+}$IFN- $\gamma^{+} \mathrm{IL}_{-1} 7^{+}$Th1/17 and $\mathrm{CD} 4^{+} \mathrm{CD} 25$ ${ }^{+}$Foxp $^{+} \mathrm{T}$ cells in individual samples were determined by flow cytometry following intracellular staining with anticytokine antibodies. Briefly, the stimulated PBMCs were harvested and stained with allophycocyanin (APC)-labeled anti-CD4, fixed with the Perm/Fix solution, and permeabilized, followed by staining with fluorescein isothiocyanate (FITC)-labeled anti-IL-17 and PE-Cy7labeled anti-IFN- $\gamma$ (Becton Dickinson, San Diego, USA). Additional cells were stained in duplicate with PerCP-anti-CD4/FITC-anti-CD25 or isotype-matched controls (BD PharMingen, San Diego, USA) for $30 \mathrm{~min}$, fixed, and permeabilized using the permeabilization solution (BD Biosciences), followed by intracellular staining with PE-anti-Poxp-3 (BD PharMingen, San Diego, USA). After being washed with PBS, these cells were analyzed on a FACSCalibur (BD Biosciences, San Jose, USA) and at least 20,000 events were analyzed by FlowJo software (v7.6.2).

\section{Cytometric bead array for the level of serum cytokines}

The concentrations of serum IFN- $\gamma$, TNF- $\alpha$, IL-2, IL-4, IL6 , IL-10 and IL-17 were determined by cytometric bead array (CBA), according to the manufacturer's protocol (CBA, BD Biosciences) with minor modification. Briefly, $50 \mu \mathrm{L}$ serum samples were subjected to analysis in duplicate using the cytometric bead array kit on a FACSCalibur cytometry. The concentration of serum cytokines were quantified using CellQuestPro and CBA software (Becton Dickinson). The detection limit for IFN- $\gamma$, TNF- $\alpha$, IL-2, IL-4, IL-6, IL-10 and IL-17 were $4.1 \mathrm{pg} / \mathrm{ml}, 3.7 \mathrm{pg} / \mathrm{ml}$, $2.9 \mathrm{pg} / \mathrm{ml}, 3.3 \mathrm{pg} / \mathrm{ml}, 2.5 \mathrm{pg} / \mathrm{ml}, 3.3 \mathrm{pg} / \mathrm{ml}$, and $4.2 \mathrm{pg} / \mathrm{ml}$, respectively.

\section{Statistical analysis}

Data were expressed as median and range for each group unless specified. The difference between groups was analyzed by the Kruskal-Wallis test or Chi-square test using SPSS 16.0 software for unpaired and paired comparisons, respectively. The relationship between variables was evaluated using the Spearman rank correlation test. A two-side $P$ value $<0.05$ was considered statistically significant.

\section{Results}

\section{Patient sociodemographic and clinical characteristics}

The sociodemographic and clinical characteristics of RTR's are summarized in Table 1. The patients displayed higher concentration of serum creatinine and BUN and lower level of eGFR. Furthermore, significantly higher levels of white blood cell (WBC), and lower levels of red blood cell (RBC) and hemoglobin $(\mathrm{Hb})$ were detected in ESRF, compared to the HCs.

RTR's were divided into four groups according to graft function (based on eGFR or serum creatinine level) and post-transplant rejection time (Table 2). TS Patients showed a significant reduction in BUN and $\mathrm{Cr}$ levels and a significant increase in eGFR values and $\mathrm{Hb}$ compared to the pre transplant status. In addition, the concentration of serum $\mathrm{Cr}$ and BUN in AMR, AR and CR groups were significantly higher than TS ESRF patients.

\section{CD4 ${ }^{+}$IFN- $\gamma^{-}$IL- $17^{+}$Th17, CD4 ${ }^{+}$IFN $-\gamma^{+}$IL- $17^{-}$Th1 and CD4 ${ }^{+}$IFN $-\gamma^{+}$IL-17 ${ }^{+}$Th1/17 T cells in the patients} The circulating $\mathrm{CD}^{+}{ }^{+} \mathrm{T}$ cells analysis (Fig. 1a-g) found that, the number of $\mathrm{CD}^{+}, \mathrm{CD} 4^{+} \mathrm{IFN}-\gamma^{-} \mathrm{IL}-17^{+}$Th17, 
Table 1 The demographic and clinical characteristics of subjects

\begin{tabular}{lll}
\hline Parameters & $\mathrm{HC}$ & ESRF \\
\hline Number & 10 & 35 \\
Age (years) & $37(30-45)$ & $38(31-48)$ \\
$\mathrm{F} / \mathrm{M}(\mathrm{n})$ & $4 / 6$ & $15 / 20$ \\
$\mathrm{BUN}(\mathrm{mmol} / \mathrm{L})$ & $4.4(3.5-7.0)$ & $16.8(7.2-32.8)^{*}$ \\
$\mathrm{Cr}(\mathrm{umol} / \mathrm{L})$ & $88(65-112)$ & $832(499-1790)^{*}$ \\
eGFR $(\mathrm{ml} / \mathrm{min})$ & $115(98-124)$ & $21(8-67)^{*}$ \\
$\mathrm{WBC}\left(\times 10^{9} / \mathrm{L}\right)$ & $7.7(3.6-9.4)$ & $10.9(8.5-13.9)^{*}$ \\
$\mathrm{PBMCs}\left(\times 10^{9} / \mathrm{L}\right)$ & $2.7(0.9-4.5)$ & $2.1(1.1-3.3)^{*}$ \\
$\mathrm{RBC}\left(\times 10^{12} / \mathrm{L}\right)$ & $4.0(3.7-4.6)$ & $2.4(1.7-3.1)$ \\
$\mathrm{Hb}(\mathrm{g} / \mathrm{L})$ & $128(111-147)$ & $85(66-107)$ \\
\hline
\end{tabular}

Data shown are median (range) of each group of subjects

ESRF End-stage renal failure, BUN Blood urea nitrogen (normal range:

$3.2 \sim 6.0 \mathrm{mmol} / \mathrm{L}$ ), $\mathrm{Cr}$ Serum creatinine (normal ranges: men: 44-133umol/L;

women: 70-108umol/L), eGFR Glomerular filtration rate (normal value: $125 \mathrm{ml}$ / $\mathrm{min}$ ), $W B C$ White blood cell (normal range: $4 \sim 10 \times 10^{9} / \mathrm{L}$ ), RBC: Normal range: men, $4.0 \sim 5.5 \times 10^{12} / \mathrm{L}$; women, $3.5 \sim 5.0 \times 10^{12} / \mathrm{L} ; \mathrm{Hb}$ : normal range: men $120-160 \mathrm{~g} / \mathrm{L} ;$ women, $110-150 \mathrm{~g} / \mathrm{L}$

${ }^{*} P<0.05$ vs. The HC

$\mathrm{CD} 4^{+} \mathrm{IFN}-\gamma^{+} \mathrm{IL}-17^{-}$Th1 and $\mathrm{CD} 4^{+} \mathrm{IFN}-\gamma^{+} \mathrm{IL}-17^{+}$Th1/17 cells (Fig. 1a, d-f) in patients with ESRF were significantly greater than the HCs. In contrast, there was no significant difference in the number of $\mathrm{CD} 4^{+} \mathrm{CD} 25^{+} \mathrm{Foxp}^{+} \mathrm{T}$ cells (Fig. 1b) between the ESRF patients and HCs. As a result, the ratio of $\mathrm{CD} 4^{+} \mathrm{CD} 25^{+} \mathrm{Foxp}^{+}{ }^{+} \mathrm{T}$ cells to $\mathrm{CD} 4^{+} \mathrm{IFN}-\gamma^{-} \mathrm{IL}-$ $17^{+}$Th17 cells (Fig. 1g) was significantly lower in ESRF patients compared to the HCs. Furthermore, there was no significant difference in the ratio of CD $4^{+} \mathrm{CD} 25^{+} \mathrm{Foxp}^{+}{ }^{+} \mathrm{T}$ cells to $\mathrm{CD} 4^{+} \mathrm{IFN}-\gamma^{+} \mathrm{IL}_{-}-17^{-}$Th1 or $\mathrm{CD}^{+} \mathrm{IFN}-\gamma^{+} \mathrm{IL}-17^{+}$Th1/17 cells between ESRF patients and the HCs.
The number of CD4 + IFN- $\gamma-$ IL-17+ Th17, CD4 + IFN- $\gamma+$ IL17- Th1, CD4 + IFN- $\gamma+$ IL-17+ Th1/17 T and CD4 + CD25 + Foxp3+ T cells

Further comparison of different types of $\mathrm{CD}^{+} \mathrm{T}$ cells (Fig. 2a-g) found that, in post-transplant TS patients, the number of $\mathrm{CD}^{+} \mathrm{CD} 25^{+} \mathrm{Foxp}^{+} \mathrm{T}$ cells and the ratio of Tregs to Th17 were significantly increased (Fig. 2c, g), whereas the number of $\mathrm{CD} 4^{+}, \mathrm{CD} 4^{+} \mathrm{IFN}-\gamma^{-} \mathrm{IL}-17^{+}$Th17, $\mathrm{CD} 4^{+}$IFN $-\gamma^{+} \mathrm{IL}-17^{-}$Th1 and CD $4^{+} \mathrm{IFN}-\gamma^{+} \mathrm{IL}-17^{+}$Th1/17 cells were significantly decreased compared to the pretransplant status. (Fig. 2b, d-f). Conversely, in the AMR, $\mathrm{AR}$ and $\mathrm{CR}$ patients, the number of $\mathrm{CD} 4^{+} \mathrm{CD} 25^{+} \mathrm{Foxp}^{+} \mathrm{T}$ cells is decreased while the numbers of $\mathrm{CD} 4^{+} \mathrm{IFN}-\gamma^{-} \mathrm{IL}-17^{+}$ Th17, CD4 $4^{+}$IFN- $\gamma^{+} \mathrm{IL}-17^{-}$Th1 and CD $4^{+} \mathrm{IFN}-\gamma^{+} \mathrm{IL}-17^{+}$ Th1/17 cells are increased (Fig. 2b-g). Moreover, there was no significant change in the ratio of Tregs to Th1 cells in the pre- and post-transplant status. Interestingly, AMR patients displayed higher number of $\mathrm{CD} 4^{+}, \mathrm{CD} 4^{+} \mathrm{IFN}-\gamma^{-} \mathrm{IL}-$ $17^{+}$Th17, CD $4^{+}$IFN- $\gamma^{+} \mathrm{IL}_{-1} 7^{-}$Th1 and CD $4^{+} \mathrm{IFN}-\gamma^{+} \mathrm{IL}-17^{+}$ Th1/17 cells and lower number of $\mathrm{CD} 4^{+} \mathrm{CD} 25^{+} \mathrm{Foxp}^{+} \mathrm{T}$ cells compared to AR and CR patients. These data suggested that altered $\mathrm{CD} 4{ }^{+} \mathrm{T}$ cells number may be associated with renal transplantation rejection.

\section{Serum Th1- and Th17-type cytokines in RTR patients}

The concentration of serum IL-2, IFN- $\gamma$, TNF- $\alpha$, IL-4, IL-6, IL-10 and IL-17 in ESRF patients were significantly increased compared to the HC's (Fig. 3a). The serum cytokines level were determined and found significantly increased serum levels of IL-2, IFN- $\gamma$, TNF- $\alpha$ and IL-17 in post-transplant TS's compared to the pre-transplant patients. TS patients showed an increased level of serum IL-10 compared to the pre-transplant RTR's (Fig. 3b). However, there was no significant difference in the

Table 2 Clinical characteristics of before and post-transplant patients

\begin{tabular}{|c|c|c|c|c|c|c|c|c|}
\hline & \multicolumn{2}{|c|}{$\begin{array}{l}\text { Transplant stable } \\
(n=13)\end{array}$} & \multicolumn{2}{|c|}{$\begin{array}{l}\text { Acute antibody mediated } \\
\text { acute rejection }(n=8)\end{array}$} & \multicolumn{2}{|c|}{$\begin{array}{l}\text { Acute rejection } \\
(n=7)\end{array}$} & \multicolumn{2}{|c|}{$\begin{array}{l}\text { Chronic rejection } \\
(n=7)\end{array}$} \\
\hline & Before & After & Before & After & Before & After & Before & After \\
\hline $\begin{array}{l}\text { BUN (mmol/ } \\
\text { L) }\end{array}$ & $\begin{array}{l}17.5(7.2- \\
32.8)\end{array}$ & $7.4^{*}(3.7-10.6)$ & $\begin{array}{l}16.2(10.1- \\
28.4)\end{array}$ & $29.1 *(22.3-38.9)$ & $\begin{array}{l}16.2(14.4- \\
20.6)\end{array}$ & $\begin{array}{l}25.2^{*}(17.9- \\
34.7)\end{array}$ & $\begin{array}{l}16.5(9.2- \\
22.6)\end{array}$ & $\begin{array}{l}18.3^{*}(13.5- \\
26.8)\end{array}$ \\
\hline $\mathrm{Cr}$ (umol/L) & $\begin{array}{l}779(499- \\
1790)\end{array}$ & $130^{*}(72-352)$ & $\begin{array}{l}798(739- \\
1682)\end{array}$ & $\begin{array}{l}1387^{*}(1098- \\
1786)\end{array}$ & $\begin{array}{l}789(762- \\
1562)\end{array}$ & $\begin{array}{l}987^{*}(794- \\
1682)\end{array}$ & $\begin{array}{l}786(698- \\
1492)\end{array}$ & $578^{*}(512-755)$ \\
\hline $\begin{array}{l}\text { eGFR (ml/ } \\
\text { min) }\end{array}$ & $20(8-67)$ & $88^{*}(59-101)$ & $27(8-62)$ & $9^{*}(4-13)$ & $21(9-59)$ & $12^{*}(6-24)$ & $24(9-51)$ & $18^{*}(5-35)$ \\
\hline WBC $\left(\times 10^{9} / L\right)$ & $9.8(8.5-13.4)$ & $7.9^{*}(6.3-9.7)$ & $9.7(8.9-13.9)$ & $17.7^{*}(11.8-19.6)$ & $9.6(8.8-11.6)$ & $\begin{array}{l}13.1^{*}(9.9- \\
16.2)\end{array}$ & $9.7(8.6-13.2)$ & $11.7^{*}(9.6-13.7)$ \\
\hline $\begin{array}{l}\text { PBMCs }\left(\times 10^{9} /\right. \\
\text { L) }\end{array}$ & $1.7(1.1-2.9)$ & $0.8^{*}(0.6-1.0)$ & $1.7(1.3-3.3)$ & $0.3^{*}(0.1-0.6)$ & $1.9(1.4-3.1)$ & $0.7^{*}(0.4-1.0)$ & $1.7(1.1-2.7)$ & $0.7^{*}(0.9-1.2)$ \\
\hline $\mathrm{RBC}\left(\times 10^{12} / \mathrm{L}\right)$ & $2.4(2.1-2.7)$ & $3.1^{*}(2.6-3.3)$ & $2.0(1.7-2.5)$ & $1.5^{*}(1.3-2.0)$ & $2.1(1.9-3.1)$ & $1.9^{*}(1.7-2.3)$ & $2.0(1.9-2.9)$ & $2.3^{*}(2.0-2.8)$ \\
\hline $\mathrm{Hb}(\mathrm{g} / \mathrm{L})$ & $\begin{array}{l}86.0(73.0- \\
99.0)\end{array}$ & $\begin{array}{l}97.0^{*}(88.0- \\
103.0)\end{array}$ & $\begin{array}{l}82.0(66.0- \\
91.0)\end{array}$ & $73.0^{*}(61.0-77.0)$ & $\begin{array}{l}87.0(69.0- \\
103.0)\end{array}$ & $\begin{array}{l}78.0^{*}(67.0- \\
89.0)\end{array}$ & $\begin{array}{l}84.0(69.0- \\
107)\end{array}$ & $\begin{array}{l}91.0^{*}(80.0- \\
110.0)\end{array}$ \\
\hline
\end{tabular}

Data are expressed as median (range) or real case numbers

* $P<0.05$ vs, before transplant rejection 


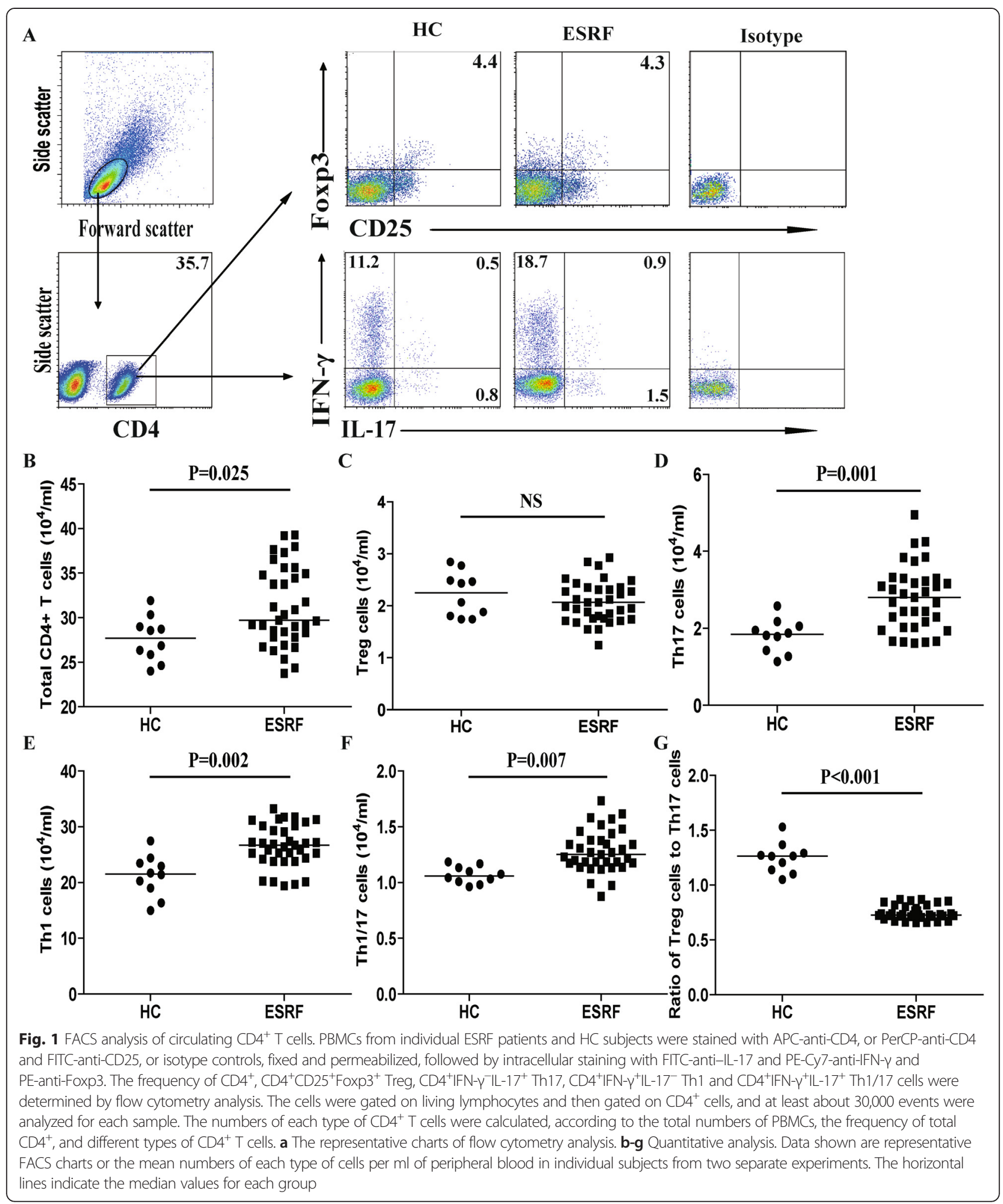

concentrations of IL-4 and IL- 6 pre and post-transplant. These data indicated that higher serum levels of Th17- and Th1-type cytokines may be associated with renal transplantation rejection.
The correlation of Tregs with Th17 cells in RTR patients

The potential relationship between the concentration of serum inflammatory cytokines and the number of different subsets of $\mathrm{CD}^{+} \mathrm{T}$ cells in RTR patients was analyzed 


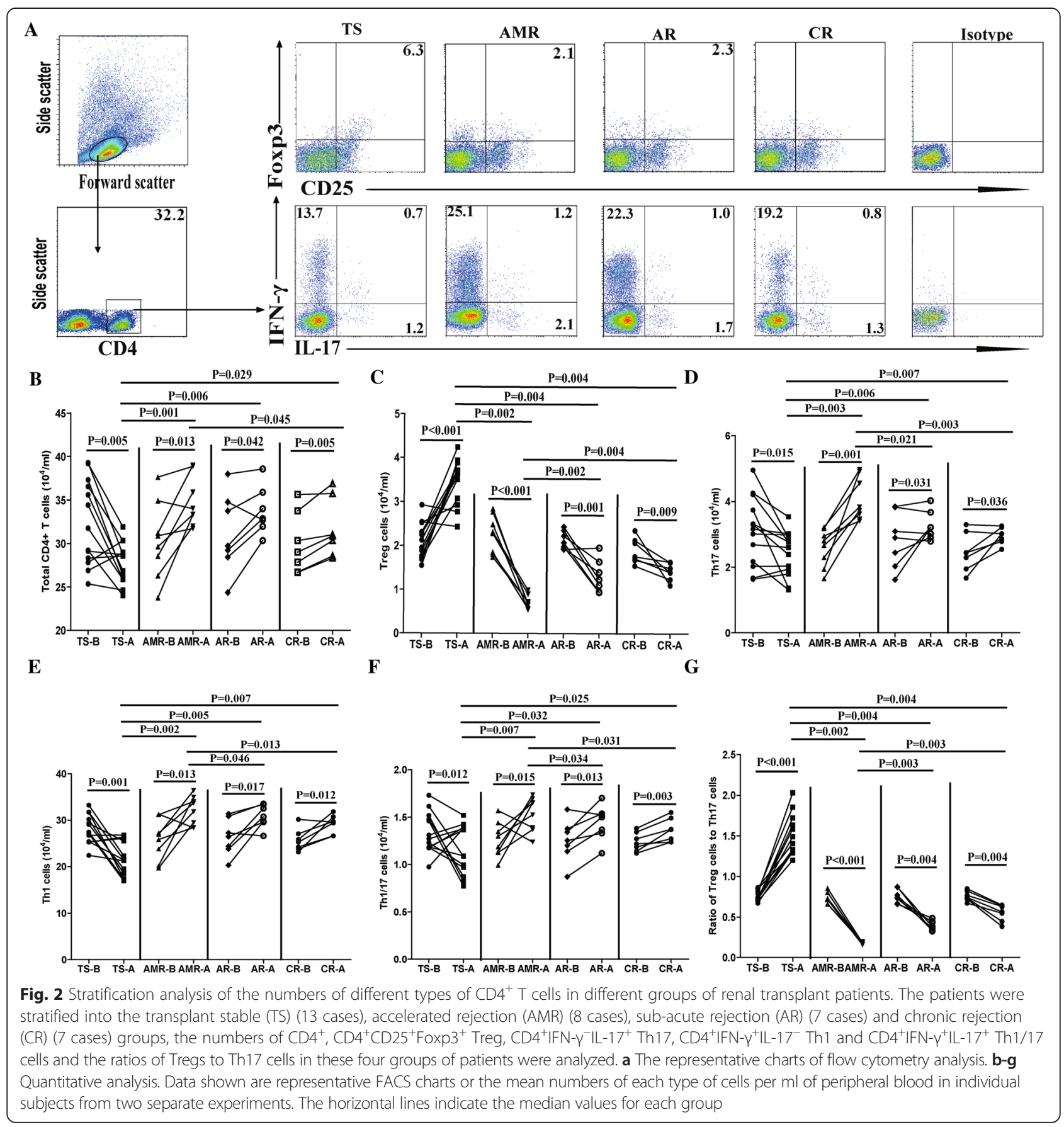

(Fig. 4a-d). It was found that, the concentration of serum IL-17 and IFN- $\gamma$ was positively correlated with the number of $\mathrm{CD} 4^{+} \mathrm{IFN}-\gamma^{-} \mathrm{IL}-17^{+}$Th17 and CD $4^{+} \mathrm{IFN}-\gamma^{+} \mathrm{IL}-17^{-}$Th1 cells, respectively, in the four groups. Further analysis of the relationship found a negative association between the number of $\mathrm{CD} 4^{+} \mathrm{CD} 25^{+} \mathrm{Foxp}^{+} \mathrm{T}$ cells and the number of CD $4^{+}$IFN- $\gamma^{-}$IL- $17^{+}$Th17 cells in the four groups. These data suggested that different types of $\mathrm{CD}^{+} \mathrm{T}$ cells may have variable functions during renal transplantation rejection.
The relationship between the number of $\mathrm{CD}^{+} \mathrm{T}$ cells or inflammatory cytokines and clinical parameters in TS patients

To understand the importance of different subsets of CD4 ${ }^{+}$ $\mathrm{T}$ cells and inflammatory cytokines, we analyzed the potential association of the number of different types of $\mathrm{CD}^{+} \mathrm{T}$ cells and inflammatory cytokines with clinical parameters of the patients. It was found that the number of CD4 + CD25 + Foxp3+ and CD4 + IFN- $\gamma$-IL-17+ Th17 cells were positively correlated with the eGFR value and serum 


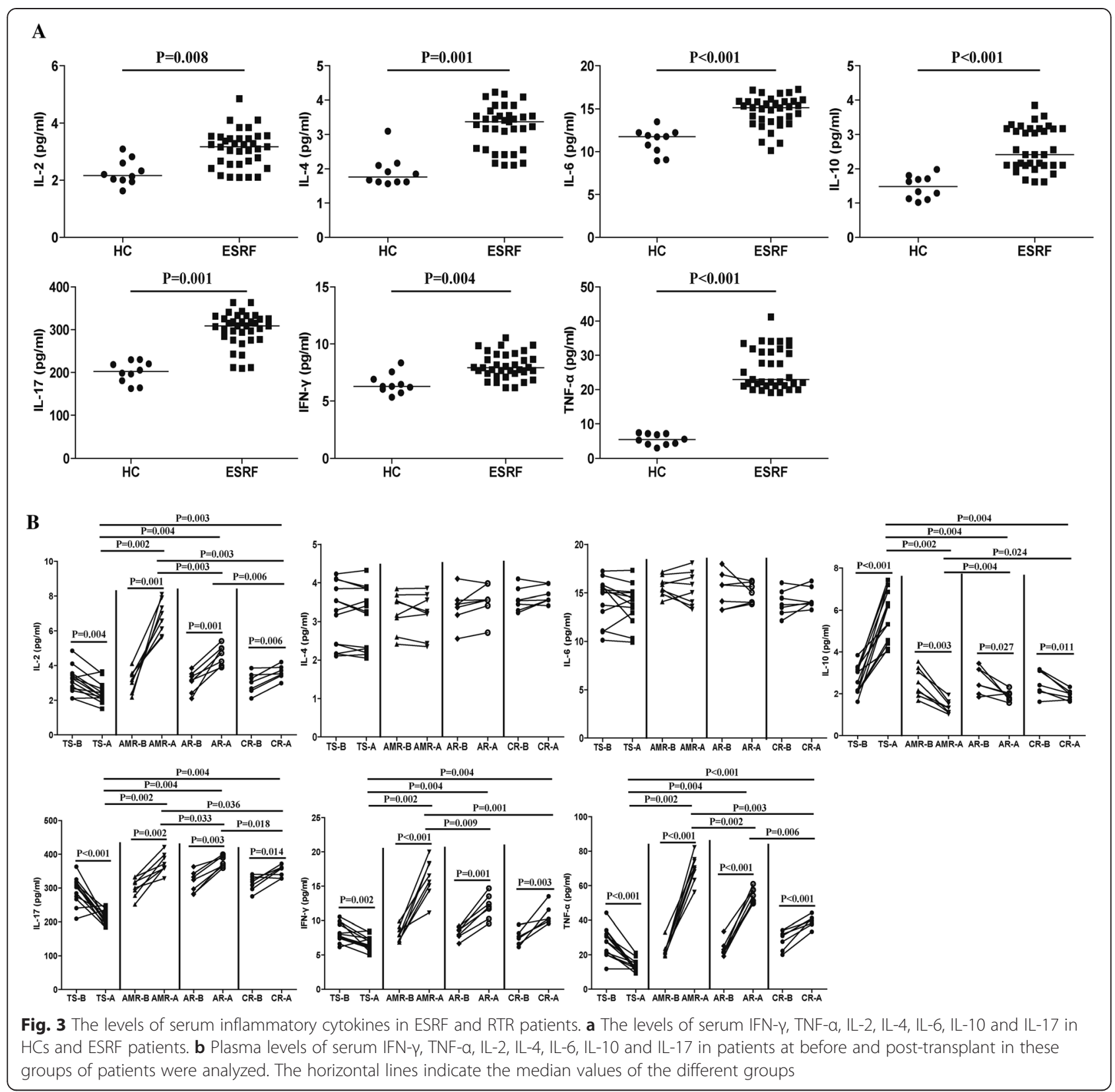

creatinine level, respectively, in the TS group (Fig. 5). Further analysis revealed that the serum level of TNF- $\alpha$ and IL-17 were positively correlated with serum creatinine level. In contrast, the serum level of IL-10 was negatively correlated with serum creatinine in the TS group. Moreover, three groups of RTR also showed the same trend (data not shown).

\section{Discussion}

Although renal transplantation provides a readily accessible alternative strategy for patients with end-stage renal failure, immune rejection remains a major hurdle to its implementation. In this study, we examined the pre and post- transplantation number of different types of circulating $\mathrm{CD} 4^{+} \mathrm{T}$ cells in ESRF patients. The study found that, the number of $\mathrm{CD} 4^{+} \mathrm{IFN}-\gamma^{-} \mathrm{IL}-17^{+}$Th17, $\mathrm{CD} 4^{+} \mathrm{IFN}-\gamma^{+} \mathrm{IL}-17^{-}$ Th1 and CD4 $4^{+}$IFN- $\gamma^{+} \mathrm{IL}-17^{+}$Th1/17 cells in ESRF patients were significantly increased compared to the $\mathrm{HC}$, whereas there was no significant difference in the number of CD4 ${ }^{+} \mathrm{CD} 25^{+} \mathrm{Foxp}^{+}{ }^{+} \mathrm{T}$ cells between patients and HC's. Apparently, there was an imbalance of Tregs to Th17 cells in ESRF patients. Together these data suggested that dysregulated $\mathrm{CD} 4^{+} \mathrm{T}$ cells play an important role in ESRF patients, which were consistent with previous studies [36]. Moreover, RTR showed increased number of $\mathrm{CD} 4^{+} \mathrm{IFN}-\gamma^{-} \mathrm{IL}-17^{+}$ Th17, CD $4^{+} \mathrm{IFN}-\gamma^{+} \mathrm{IL}-17^{-}$Th1 and $\mathrm{CD} 4^{+} \mathrm{IFN}-\gamma^{+} \mathrm{IL}-17^{+}$ 


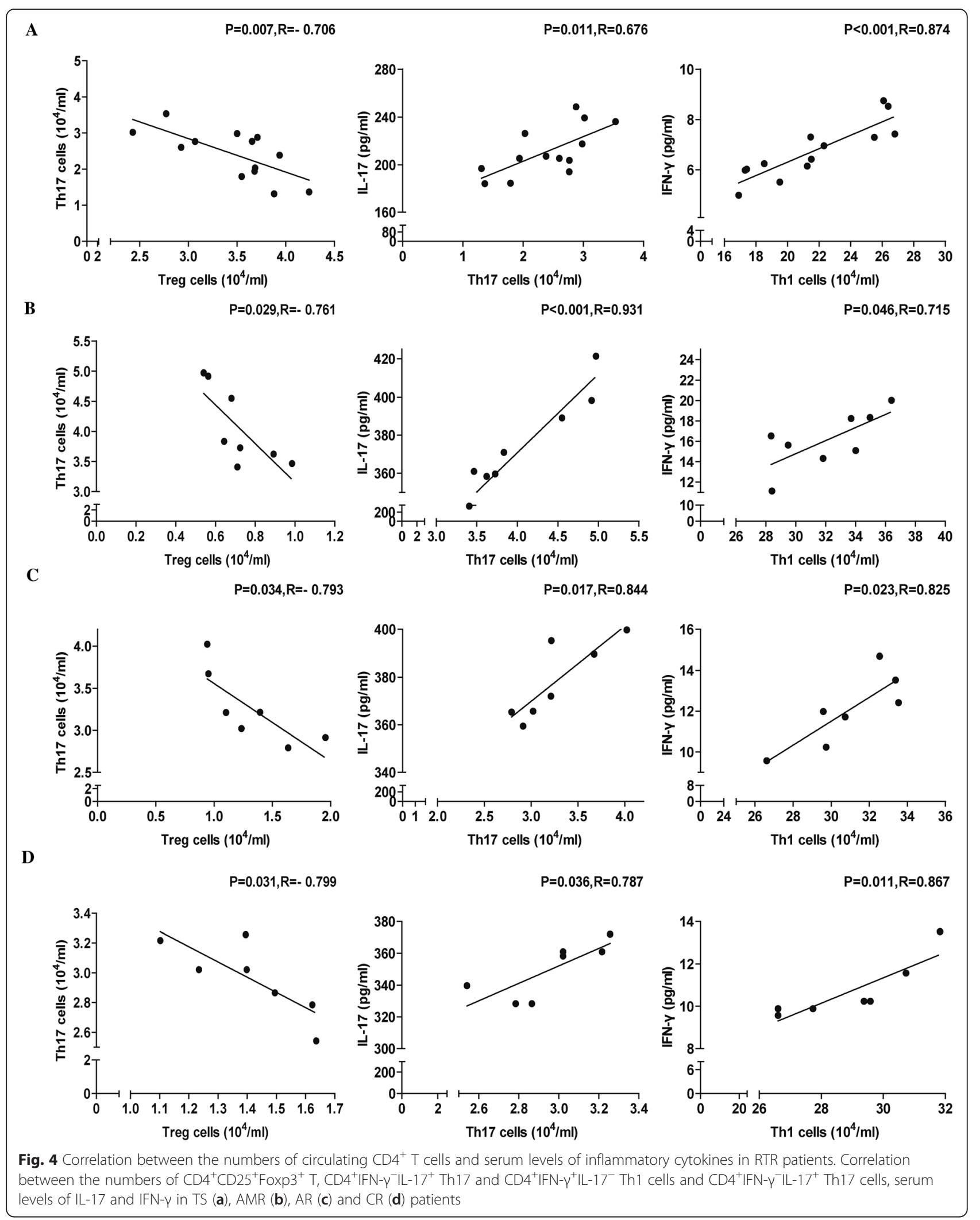




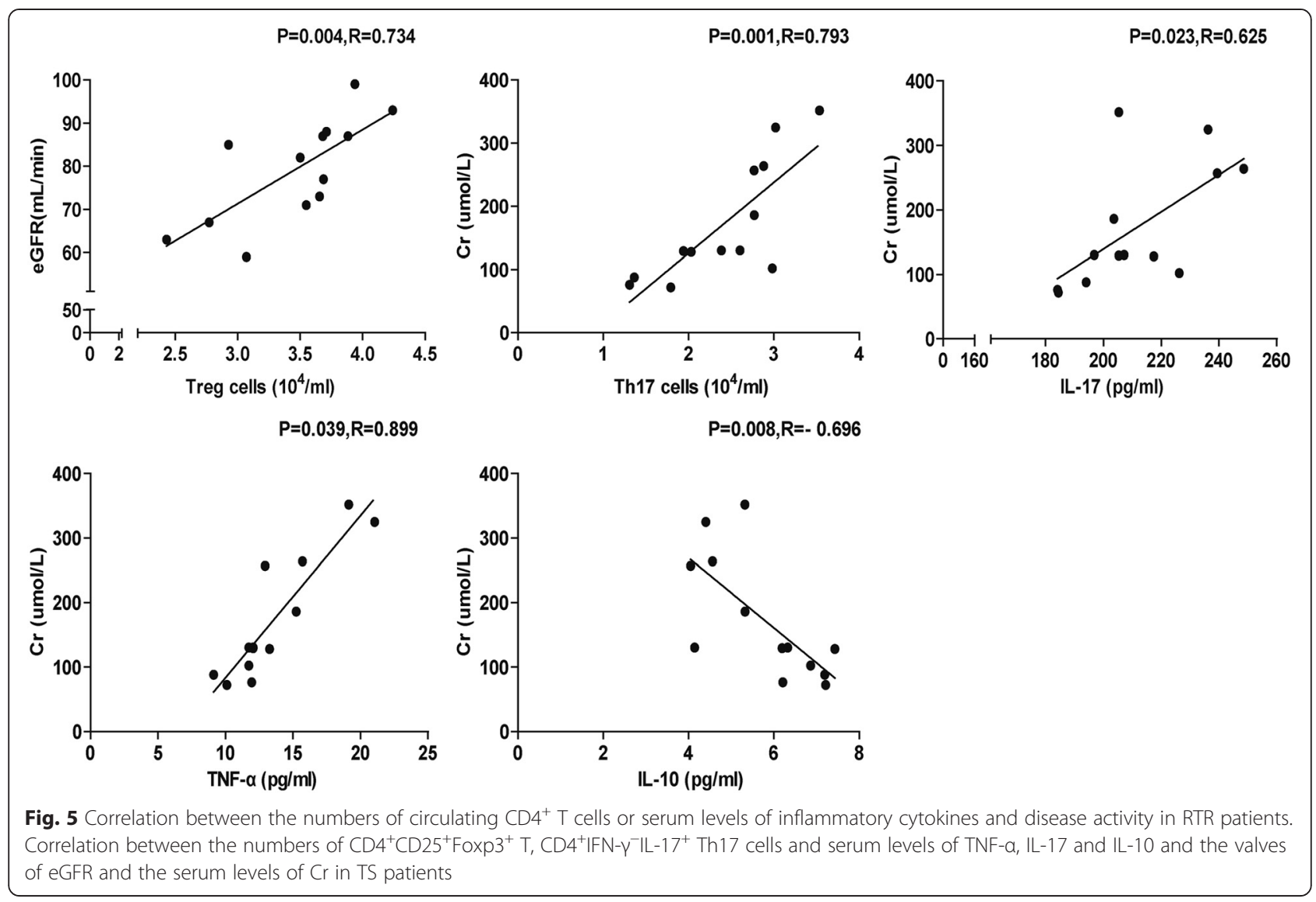

Th1/17 cells and higher levels of serum IL-2, IFN- $\gamma$, TNF- $\alpha$ and IL-17, but decreased number of $\mathrm{CD} 4^{+} \mathrm{CD} 25^{+} \mathrm{Foxp} 3^{+} \mathrm{T}$ cells and lower levels of serum IL-10 compared to pretransplant and TS's patients. Conceivably, an imbalance in $\mathrm{CD}_{4}{ }^{+} \mathrm{T}$ cells and inflammatory cytokines were new target for immunotherapy for the intervention of renal transplantation.

Increasing evidences have shown that multiple subsets of effector $\mathrm{CD}_{4}^{+} \mathrm{T}$ cells play an important role in allograft rejection [37, 38]. In addition to direct killing activity by cytotoxic $\mathrm{T}$ lymphocytes, organ allotransplantation rejection can occur through T-cell-mediated mechanisms, including cytokine production, recruitment and activation of other cytotoxic cells as well as B cells that produce xenoreactive antibodies [39]. This study demonstrated that after renal transplant, patients showed increased number of $\mathrm{CD} 4{ }^{+} \mathrm{IFN}$ $\gamma^{+} \mathrm{IL}-17^{-}$Th1 cells and Th1-type cytokines (IL-2, IFN- $\gamma$, TNF- $\alpha$ ) compared to the pre-transplant and TS patients, which was consistent with previous reports [40-42]. Similarly, we detected significantly higher levels of cytokines in post-transplant patients compared to pre-transplant. Moreover, the number of $\mathrm{CD} 4^{+} \mathrm{IFN}-\gamma^{+} \mathrm{IL}-17^{-}$Th1 cells was positively correlated with the concentration of serum IFN- $\gamma$ in all the four post-transplant groups. However, there was no significant difference in the Th2-type cytokines (IL-4, IL-6) before and after transplant. These data suggested that Th1, not Th2, likely play an important role in rejection, which were consistent with Yuxin and coworkers [43]. The significantly changed Th1 cells may stem from the inflammatory environment, which preferably activate naive helper $\mathrm{T}$ cells towards Th1 direction. In addition to Th1 cells, Th17 cells expressing retinoic acid-related orphan receptor $\gamma \mathrm{t}(\mathrm{ROR} \gamma \mathrm{t})$ that play a crucial role in the development of transplant rejection by producing pro-inflammatory cytokine IL-17 [5-7]. Some studies have demonstrated that Th17 and IL17 contribute to rejection during heart, lung, liver and other organ allotransplantation $[8,9]$. Morever, similar studies have also suggested that IL-17-secreting cell infiltration is a prognostic marker for determining allograft outcome in renal allograft biopsies with acute T-cell-mediated rejection (ATCMR) $[44,45]$. However, the possible mechanisms of Th17 and IL-17 in different types of renal transplantation rejection remains unknown. Notably, we detected significantly increased number of $\mathrm{CD} 4^{+} \mathrm{IFN}-$ $\gamma^{-} \mathrm{IL}-17^{+}$Th17 cells and Th17-type cytokines (IL-17) in RTR compared to the pre-transplant status and TS patients. Moreover, the number of Th17 cells was positively correlated with serum IL-17 concentration in the posttransplant groups. These results suggested that Th17 cells, as well as Th1 cells, play a key role in renal transplantation 
rejection. More interestingly, the study found greater number of CD4 ${ }^{+}$IFN- $\gamma^{+} \mathrm{IL}_{-1} 7^{+}$Th1/17 cells in RTR group compared to pre-transplant and post-transplant TS patients. Previous studies have shown that CD $4^{+}$IFN $-\gamma^{-}$IL-17 + Th17 cells are a rare population and the development of these cells depends on the cytokine environment [46-48]. However, there was no significant correlation between the number of Th1/17 cells and the clinical parameters. It is possible that Th1/17 cells may not be potent effectors for transplant rejection. Given that, following activation, T cells can differentiate into different functional T cells, these Th1/ 17 cells may be early differentiated and uncommitted cells. We are interested to further investigating the role of Th1/ 17 cells in the renal transplantation rejection.

Similar studies have reported that $\mathrm{CD}^{+} \mathrm{CD} 25^{+} \mathrm{Foxp}^{+} \mathrm{T}$ cells play an important role in immune tolerance mechanism during renal transplantation rejection [22-24]. A study by Wen et al. [29] found that following transplantation, RTR had significantly lower levels of $\mathrm{CD} 4^{+} \mathrm{CD} 25^{+} \mathrm{Foxp}^{+} \mathrm{T}$ cells compared to ESRF and these cells had a positive linear relationship with glomerular filtration rate. This finding was consistent with our data that showed RTR had lower number of $\mathrm{CD}^{+}{ }^{+} \mathrm{CD} 25^{+}$Foxp $^{+}{ }^{+} \mathrm{T}$ cells compared to pretransplant status. This observation may partly reflect the impact of immunosuppression on this cell population. Studies of Tregs in RTR have shown variably changing circulating levels during post-transplantation, suggesting the possibility of regulatory cells production expressing Foxp3 in immunosuppressed RTR's.

Further studies on $\mathrm{CD}^{+}$T-cell subsets in RTR have indicated that the number of $\mathrm{CD} 4^{+} \mathrm{CD} 25^{+}$Foxp $3^{+} \mathrm{T}$ cells were negatively correlated with the number of $\mathrm{CD} 4^{+} \mathrm{IFN}$ $\gamma^{-}$IL-17 ${ }^{+}$Th17 cells, which was supported by molecular studies showing the presence of reciprocal interaction between these subpopulation. Though, both Th17 and Tregs require TGF- $\beta 1$ during the early stage of differentiation, in the presence of pro-inflammatory cytokines TGF- $\beta 1$ and IL-6, FoxP3 is down-regulated and T-cell with transitional phenotype express a set of proteins essential for Th17 development [49]. Additionally, IL-2, which is required for the regulation of Foxp3 expressing Tregs, has been found to inhibit the development of Th17 cells [50]. Hence, it is possible that the counteractive effects of IL- 2 and IL- 6 on the differentiation of Th17 and Treg in the periphery may hamper immunoregulatory responses and facilitate the persistence of rejection. Morever, previous studies have suggested that the FOXP3/IL-17 ratio may be a useful indicator for representing the severity of tissue injury, allograft dys-function and for predicting the clinical outcome of ATCMR [44]. However, the precise roles of Treg and Th17 cells in renal transplantation rejection need to be further explored. Morever, our study showed that there was no correlation between the number of $\mathrm{CD}^{+} \mathrm{CD} 25$ ${ }^{+} \mathrm{Foxp}^{+} \mathrm{T}$ cells and the number of $\mathrm{CD} 4^{+} \mathrm{IFN}-\gamma^{+} \mathrm{IL}-17^{-}$
Th1 cells, which was inconsistent with previous research that showed suppression of Th1 cell-mediated responses by Tregs through inhibition of monocyte-derived IL-6 [30]. This possibility could be attributed to the difference in the internal circumstances of the patients. Previous studies have reported that multiple inflammatory cytokines played a key role in transplantation rejection response [31-33], such as Th1-type (IL-2, IFN- $\gamma$, TNF- $\alpha$ ) and Th17-type (IL17) cytokines. IL-2 is the critical mediator of acute rejection whereas IFN- $\gamma$ can mediate separate functions at the same target organ during Graft-versus-host disease (GVHD) [30-32]. TNF- $\alpha$ is a lymphocyte and macrophage derived cytokine that is pleiotropic in its actions. Its proinflammatory function suggest that it may play an important role in initiating and orchestrating the rejection response. Studies demonstrating a correlation in the expression of TNF-alpha with the severity of the rejection episode have placed TNFalpha as a prime candidate marker of transplantation rejection [51, 52]. IL10 is a potent synthesis inhibitory factor and anti-inflammatory, and is an important immunoregulatory component in the cytokine network of RTR's [53]. IL17 can induce the expression of proinflammatory TNF- $\alpha$, and MCP-1 and MIP-1 to promote tissue inflammation [33]. In the present study, we found that RTR patients displayed higher levels of serum IL-2, IFN- $\gamma$, TNF- $\alpha$ and IL-17, but not IL-4 and IL-6, whereas TS patients displayed higher levels of serum IL-10 compared to pre-transplant status. More importantly, the serum levels of TNF- $\alpha$ and IL-17 were positively correlated with the concentrations of serum $\mathrm{Cr}$, whereas IL-10 level was negatively correlated with the concentration of serum $\mathrm{Cr}$ in all the four posttransplant groups. These data indicated that an imbalance of serum Th1- and Th17-type cytokines may be a positive regulator during renal transplantation rejection process. Conceivably, the change in inflammatory cytokines may be a new target for designing immunotherapy for the intervention of renal transplantation rejection response.

\section{Conclusion}

In summary, our data showed a significantly increased number of circulating Th1 and Th17 cells as well as higher levels of serum inflammatory cytokines in ESRF patients. RTR displayed lower number of Tregs, Treg to Th17 cells ratio and serum IL-10, and higher numbers of Th1 and Th17 and related cytokines compared to the pre-transplant and post-transplant TS patients. These novel finding suggested that effector $\mathrm{CD}^{+} \mathrm{T}$ cells may be controlled by Tregs during renal transplantation rejection and the imbalance of Treg/Th17 axis may be associated with the process of renal transplantation rejection. The limitations of this study include small sample size and lack of functional studies of different types of $\mathrm{CD}^{+} \mathrm{T}$ cells. Thus, further studies in larger population are warranted. 


\section{Competing interests}

The authors declare that they have no competing interests.

\section{Authors' contributions}

YJ conceived the study. LM performed the experiments and wrote the manuscript. $\mathrm{HZ}$ performed allmathematical and statistical analysis. KH, GL and YF interpreted the analysis results and planned the validation experiments. PZ supervised the experiments. All authors read and approved the final manuscript.

\section{Acknowledgements}

This study was supported by grants from the National Natural Science Foundation of China (No. 30972610 and 81273240), Jilin Province Science and Technology Agency (No.20110716), the Health Department Research Projects in Jilin Province (2009Z054), and Norman Bethune Program of Jilin University (2012206).

\section{Author details \\ ${ }^{1}$ Genetic Diagnosis Center, The First Hospital of Jilin University, Changchun 130021, China. ${ }^{2}$ Department of Nephrology, The First Hospital of Jilin University, Changchun 130021, China. ${ }^{3}$ Department of Gastroenterology, The First People's Hospital of Changzhou, Third Affiliated Hospital of Suzhou University, Changzhou, Jiangsu 213003, China. ${ }^{4}$ Department of Medical Laboratory Sciences, Haramaya University, Haramaya, Ethiopia. ${ }^{5}$ Jiangsu Co-innovation Center for Prevention and Control of Important Animal Infectious Diseases and Zoonoses, Yangzhou 225009, China.}

\section{Received: 27 September 2014 Accepted: 2 September 2015} Published online: 23 September 2015

\section{References}

1. Hatem A, Cosio FG. Significance and management of Proteinuria in kidney transplant recipients. J The Am Soc Nephrol. 2009;9:2490-2.

2. Sadeghi M, Daniel V, Naujokat C, Mehrabi A, Opelz G. Association of high pretransplant sIL-6R plasma levels with acute tubular necrosis in kidney graft recipients. Transplantation. 2006;81:1716-24.

3. Lu $\sqcup$, Sun JB, Liu ZG, Gong X, Cui JL, Sun XG. Immune responses following mouse peripheral nerve xenotransplantation in rats. J Biomed Biotechnol. 2009. doi:10.1155/2009/412598.

4. Fox IK, Jaramillo A, Hunter DA, Rickman SR, Mohanakumar T, Mackinnon SE et al. Prolonged cold-preservation of nerve allografts. Muscle Nerve. 2005;31:59-69.

5. Choi SW, Levine JE, Ferrara JL. Pathogenesis and management of graft-versus-host disease. Immunol Allergy Clin North Am. 2010;30(1):75-101.

6. Shimabukuro-Vornhagen A, Hallek MJ, Storb RF, von Bergwelt-Baildon MS. The role of B cells in the pathogenesis of graft-versus-host disease. Blood. 2009;114(24):4919-27.

7. Socie G, Blazar BR. Acute graft-versus-host disease:from the bench to the bedside. Blood. 2009;114(20):4327-36.

8. Vanandenaerde BM, Wuyts WA, Dupont $\sqcup$, Van RD, Demedts MM, Verleden GM. Intefleukin $\cdot 17$ stimulates release of intedeukin-17 human airway smooth muscle ceils in vitro:a potential role for interieukin-17 and airway smooth nlnucle ceils in bronchiolitis oblitermH syndrome. Heart hmg Transplant. 2003;22(11):1280-3.

9. Li JQ, Simecni E, Fleury S, Dudhr J, Fiorini E, Kappenberger L. Gene transfer of soluble interleukin-17 receptor prolongs cardiac allossurvival in a rat model. Eur J Cardiothorac Surg. 2006;29(5):779-83.

10. Sakaguchi S. Naturally arising CD4 + regulatory T cells for immunologic self-tolerance and negative control of immune responses. Annu Rev Immunol. 2004;22:531-62.

11. Weaver CT, Hatton RD, Mangan PR, Harrington LE. IL-17 family cytokines and the expanding diversity of effector T cell lineages. Annu Rev Immunol. 2007;25:821-52.

12. Crome SQ, Wang AY, Levings MK. Translational Mini-Review Series on Th17 Cells: Function and regulation of human T helper 17 cells in health and disease. Clin Exp Immunol. 2007;159:109-19.

13. Faust SM, Lu G, Marini BL, Zou W, Gordon D, Iwakura Y, et al. Role of T cell TGF beta signaling and IL-17 in allograft acceptance and fibrosis associated with chronic rejection. J Immunol. 2009;183:7297-306.

14. Szabo SJ, Kim ST, Costa GL, Zhang X, Fathman CG, Glimcher LH. A novel transcription factor, T-bet, directs Th1 lineage commitment. Cell. 2010;100:655-69.
15. Yuan XL, Cortez JP, Knosalla IS, D'Addio F, Mfarrej B, Donnarumma M, et al. A novel role of CD4+Th17 cells in mediating cardiac allograft rejection and vasculopathy. Journal of Experimental Medicine. 2008;205:3133-44.

16. Antonysamy MA, Fanslow WC, Fu F, Li W, Qian S, Troutt AB, et al. Evidence for a role of IL-17 in organ allograft rejection: IL-17 promotes the functional differentiation of dendritic cell progenitors. J Immunol. 1999;162:577-84.

17. Buckner JH. Mechanisms of impaired regulation by CD4(+)CD25(+)FOXP3(+) regulatory T cells in human autoimmune diseases. Nat Rev Immunol. 2010;10:849-59.

18. Zhang B, Zhang X, Tang FL, Zhu LP, Liu Y, Lipsky PE. Clinical significance of increased CD4 + CD25-Foxp3+ T cells in patients with new onset systemic lupus erythematosus. Ann Rheum Dis. 2008;67:1037-40.

19. Hahn BH, Anderson M, Le E, La Cava A. Anti-DNA Ig peptides promote Treg cell activity in systemic lupus erythematosus patients. Arthritis Rheum. 2008;58:2488-97.

20. Karczewski M, Karczewski J, Kostrzewa A, Wiktorowicz K, Glyda M. The role of Foxp3+ regulatory $T$ cells in kidney transplantation. Transplant Proc. 2009;41(5):1527-9.

21. Miyara M, Sakaguchi S. Natural regulatory T cells: mechanisms of suppression. Trends Mol Med. 2007;13(3):108-16.

22. Tang Q, Bluestone JA. The Foxp3 + regulatory T cell: a jack of all trades, master of regulation. Nat Immunol. 2008;9(3):239-44.

23. Newell KA, Asare A, Kirk AD, Gisler TD, Bourcier k, Suthanthiran M, et al. Identification of a $B$ eell signature associated with renal transplant tolerance in humans. J Clin Invest. 2010;120(6):1836-47.

24. Sakaguchi S, Powrie F. Emerging challenges in regulatory $T$ cell function and biology. Science. 2007;317:627-9.

25. Feuerer M, Hill JA, Mathis D, Benoist C. Foxp3+ regulatory T cells: Differentiation, specification, subphenotypes. Nat Immunol. 2009;10:689-95.

26. Akaguchi S, Sakaguchi N, Asano M, Itoh M, Toda M. Immunologic selftolerance maintained by activated $T$ cells expressing $\mathrm{IL}-2$ receptory-chains (CD25): breakdown of a single mechanism of self-tolerance causesvarious autoimmune diseases. J Immunol. 1995;155:1151-64.

27. Ntenot JD, Gavin MA, Rudensky AY. Foxp3 programs the development and function of CD4 + CD25+ regulatory T cells. Nat Immunol. 2003;4:330-6.

28. Akaguchi S. Naturally arising Foxp3-expressing CD25 + CD4+ regulatory T cells in immunological tolerance to self and non-self. Nat Immunol. 2009;6:345-52.

29. Wen XL, Dale C, Lu LF, Matthew AR, Mauro SS, Francesco I. Foxp3+ T cells in peripheral blood of renal transplant recipients and clinical correlations. Nephrology. 2012;17:415-22.

30. Wu J, Yi S, Ouyang L, Jimenez E, Simond D, Wang W, et al. In vitro expanded human CD4 + CD25+ regulatory $T$ cells are potent suppressors of T-cell-mediated xenogeneic responses. Transplantation. 2008;85(12):1841.

31. Jasperson LK, Bucher C, Panoskaltsis-Mortari A, Taylor PA, Mellor AL, Munn DH, et al. Indoleamine 2,3-dioxygenase is a critical regulator of acute graft-versus-host disease lethality. Blood. 2008;111(6):3257-65.

32. Kolls JK, Linden A. Intedeukin-17 family members and inflammation [J]. Immunity. 2004;21(4):467-76.

33. Fossiez F, Djosson O, Chomarat P. T cell interikin-17 induces stromal cells to produce pminflammatory and hmalopoielic cytokines. Exp Med. 1996;183(6):2593-603.

34. Ruud WJ, Nicolle HR, Elly AD, Anton WL, Ashley VD, Carla CB, Willem W and Michiel GH. Uremia causes premature ageing of the T cell compartment in end-stage renal disease patients. Immunity ageing, 2012; doi:10.1186/ 1742-4933-9-19.

35. Solez K Colvin RB, Racusen LC, Sis B, Halloran PF, Birk PE, et al. Banff '05 Meeting Report: differential diagnosis of chronic allograft injury and elimination of chronic allograft nephropathy ('CAN'). Am J Transplant. 2007;7:518-26.

36. Byung HC, Kyoung WK, Bo MK, Shang GP, Sun WL, Bum SC, et al. Dysregulation of Th17 cells during the early post-transplant period in patients under calcineurin inhibitor based immunosuppression. PLoS One. 2012;7(7):e42011.

37. Dorling A, Lombardi G, Binns R, Lechler RI. Detection of primary direct and indirect human anti-porcine $T$ cell responses using a porcine dendritic cell population. Eur J Immunol. 1996;26:1378-87.

38. Davila E, Byrne GW, LaBreche PT, McGregor HC, Schwab AK, Davies WR, et al. T-cell responses during pig-to-primate xenotransplantation. Xenotransplantation. 2006;13:31-40.

39. Yang YG, Sykes M. Xenotransplantation: current status and a perspective on the future. Nat Rev Immunol. 2007;7:519-31.

40. Wang YL, Tang ZQ, Gao W, Jiang Y, Zhang XH, Peng L. Influence of Thl, Th2 and Th3 cytokines during the early phase after liver transplantation. Transplant Prec. 2003;35(8):3024-5. 
41. Lun A, Cho MY, Muller C, Staffa G, Bechstein W, Radke C, et al. Diagnostic value of peripheral blood T-cell activation and soluble IL-2 receptor for acute rejection in liver transplantation. Clin Chim Acta. 2002;320(12):69-78.

42. Boleslawski E, Conti F, Sanquer S, Philippe P, Sandrine C, Frédéric B, et al. Defective inhibition of peripheral CD8 $+\mathrm{T}$ cell $I \mathrm{~L}-2$ production by anti-calcineurin drugs during acute liver allograft rejection. Transplantation. 2004;77(12):1815-20.

43. Yu X, Jiang Y, Lu L, Xu G, Sun X, Xuan Z, et al. A crucial role of IL-17 and IFN-c during acute rejection of peripheral nerve xenotransplantation in mice. Plos One. 2012;7(3):e34419.

44. Byung HC, Hye JO, Shang GP, Hyeon SH, In OS, Sun RChoi, et al. Clinical significance of the ratio between FOXP3 positive regulatory $T$ cell and interleukin-17 secreting cell in renal allograft biopsies with acute T-cell-mediated rejection. Immunology. 2012;136(3):344-51.

45. Kyoung WK, Byung HC, Bo-Mi K, Mi-La C and Chul WY. The effect of mammalian target of rapamycin inhibition on $\mathrm{T}$ helper type 17 and regulatory $T$ cell differentiation in vitro and in vivo in kidney transplant recipients. Immunology. 2015;144(1):68-78

46. Shinji K, Heather LR, Jennifer JL, Yoshinobu K, Andrew B. Circulating Th17, Th22, and Th1 cells Are increased in psoriasis. J Invest Dermatol. 2010;130:1373-83.

47. Miossec P, Korn T, Kuchroo VK. Interleukin-17 and type 17 helper T cells. $N$ Engl J Med. 2009;361:888-98.

48. Murphy KM, Stockinger B. Effector T cell plasticity: flexibility in the face of changing circumstances. Nat Immunol. 2010;11:674-80.

49. Zhou L, Lopes JE, Chong MM. TGF-beta-induced Foxp3 inhibits $T(H) 17$ cell differentiation by antagonizing RORgammat function. Nature. 2008;453:236-40.

50. Zheng SG, Wang J, Horwitz DA. Cutting edge: Foxp3 + CD4 + CD25+ regulatory $T$ cells induced by IL-2 and TGF-beta are resistant to Th17 conversion by IL-6. J Immunol. 2008;180:7112-6.

51. Azzawi M, Hasleton PS, Hutchinson IV. TNF-alpha in acute cardiac transplant rejection. Cytokines Cell Mol Ther. 1999;5(1):41-9.

52. Newstead CG, Lamb WR, Brenchley PE, Short CD. Serum and urine IL-6 and TNF-alpha in renal transplant recipients with graft dysfunction. Transplantation. 1993;56(4):831-5.

53. Poli F, Boschiero L, Giannoni F, Tonini M, Ancona G, Scalamogna M. TNF-alpha/ INF-gamma IL-6, IL-10 and TGF-BETAL genepolymorphisms in renal allografts. Transplant Proc. 2001;33:348-9.

\section{Submit your next manuscript to BioMed Central and take full advantage of:}

- Convenient online submission

- Thorough peer review

- No space constraints or color figure charges

- Immediate publication on acceptance

- Inclusion in PubMed, CAS, Scopus and Google Scholar

- Research which is freely available for redistribution 